\begin{tabular}{cl|l}
$\begin{array}{c}\text { Cellular Physiology } \\
\text { and Biochemistry }\end{array}$ & Cell Physiol Biochem 2012;30:439-449 & \multicolumn{2}{l}{ DOI: 10.1159/000339037 } & $\begin{array}{l}\text { O 2012 S. Karger AG, Basel } \\
\text { www.karger.com/cpb }\end{array}$ \\
\cline { 2 - 3 } & $\begin{array}{l}\text { Published online: July 06, 2012 } \\
\text { Accepted: June 15, 2012 }\end{array}$ & $1015-8987 / 12 / 0302-0439 \$ 38.00 / 0$
\end{tabular}

\title{
NADPH Oxidase 2-derived Reactive Oxygen Species are Involved in Dysfunction and Apoptosis of Pancreatic $\beta$-cells Induced by Low Density Lipoprotein
}

\author{
Miao $\mathrm{Li}^{1 *}$ Lin Dou $^{1,2^{\star}}$ Juan Jiao ${ }^{1,2,3^{\star}}$ Yonggang $\mathrm{Lu}^{1,2}$ Han-Bang Guo ${ }^{1}$ Yong Man ${ }^{1}$ \\ Shu Wang ${ }^{1}$ Jian $\mathrm{Li}^{1,2}$
}

${ }^{1}$ The Key Laboratory of Geriatrics, Beijing Hospital \& Beijing Institute of Geriatrics, Ministry of Health, Beijing; ${ }^{2}$ Graduate School of Peking Union Medical College and Chinese Academy of Medical Sciences, Beijing; ${ }^{3}$ Department of Central Laboratory, General Hospital of Beijing Military Command, Beijing; *These authors contributed equally to this work

\section{Key Words}

$\mathrm{LDL} \cdot \mathrm{NIT}-1$ cells $\bullet \mathrm{NADPH}$ oxidase $2 \cdot$ Reactive oxygen species

\begin{abstract}
Background: Increased levels of plasma cholesterol are a common feature of patient of type 2 diabetes. However, the links between elevated levels of low-density lipoprotein (LDL) and dysfunction of $\beta$-cells are still unclear. Methods: The apoE $\mathrm{E}^{-/-}$mice were fed with a high-fat, cholesterol-rich diet for 8 weeks. Blood samples were collected from the mice for measurement of plasma glucose, lipids. The pancreas were embedded in OCT compound and frozen immediately in liquid nitrogen for further analysis. To examine the effects of LDL on $\beta$-cell function, insulin content, cell apoptosis and ROS production were measured in pancreatic islets of apoE $-1-$ mice and mouse pancreatic $\beta$-cell line NIT-1. Relative cell signal pathways were determined by Western blot. Results: Decreased insulin content and increased apoptosis and ROS production were found in pancreatic islets of apoE $\mathrm{E}^{-/-}$mice, accompanied by elevated plasma LDL. The ROS levels were significantly enhanced in NIT-1 cells exposed to LDL. Reduced insulin synthesis and glucose-stimulated insulin secretion and elevated apoptosis were reversed by suppression of NOX2 expression. Moreover, LDL induced dysfunction and apoptosis of pancreatic NIT-1 cells through JNK and p53 pathways, which were rescued by siRNA-mediated NOX2 reduction. Conclusions: NOX2-derived ROS may play a key role in LDL-induced dysfunction and apoptosis of pancreatic $\beta$-cells through JNK and p53 pathways.
\end{abstract}

Copyright (C) 2012 S. Karger AG, Basel 


\section{Cellular Physiology and Biochemistry}

\section{Introduction}

Type 2 diabetes is characterized by a decrease in the functional pancreatic $\beta$-cells to secrete sufficient insulin that cannot compensate for insulin resistance [1]. The dysfunction of $\beta$-cells is associated with hyperglycemia, elevated levels of plasma free fatty acids, triglycerides and low-density lipoproteins (LDL) particles as well as lower plasma level of high-density lipoprotein (HDL) cholesterol [2]. However, increased plasma cholesterol level is also a common feature of patients with type 2 diabetes. LDL is the major cholesterolcarrying lipoprotein in plasma. It has been reported that elevated LDL-cholesterol (LDL-C) can increase the risk of developing type 2 diabetes [3]. LDL can be up-taken by pancreatic $\beta$-cells mediated by LDL receptor. Cnop et al [4] reported that LDL could be internalized by receptor-mediated endocytosis and caused death of the islet $\beta$-cells. However, the mechanisms of LDL- induced $\beta$-cell dysfunction are still to be explored.

Oxidative stress plays an important role in the pathogenesis of type 2 diabetes. Reactive oxygen species (ROS) can induce dysfunction and apoptosis in pancreatic $\beta$-cells [5]. Increased generation of ROS impairs the function of $\beta$-cells and the glucose homeostasis [6]. ROS are produced via multiple processes such as the mitochondrial electron transport chain, nitric oxide synthase and xanthine oxidase, as well as a family of NADPH oxidases (NOX) [7]. The source of ROS in pancreatic $\beta$-cells has been traditionally considered to be the mitochondrial electron transport chain. Recently, it has been proved that ROS derived by NOX can lead to dysfunction of $\beta$-cells [8]. However, the cellular mechanisms involved in ROS generation in LDL-treated $\beta$-cells and the relationship between ROS and LDL-induced $\beta$ cell dysfunction are still unclear. Recently, we found that NOX is a leading candidate for ROS production in mouse pancreatic NIT-1 cells treated with glucose and free fatty acids. The analysis of expression profile of NOX family in NIT-1 cells showed expression of NOX2 and its subunits, such as p22phox, p47phox, p67phox and Rac1, but not of NOX1, NOX3, NOX4 or NOX5 in NIT-1 cells[7]. In the present study, we suggest that NOX2-derived ROS contribute to $\beta$-cell dysfunction induced by high concentration of LDL. Suppression of NOX2 substantially reversed LDL-induced dysfunction of NIT-1 cells.

\section{Materials and Methods}

Animals

10-week-old male apoE $\%$ mice on a C57BL/6J background were provided from Peking University Health Science Center (purchased from Jackson Laboratory). The apoE $\mathrm{E}^{-/}$mice $(\mathrm{n}=5)$ were fed with a high-fat, cholesterol-rich diet containing $21 \%$ fat, $19.5 \%$ casein, and $1.25 \%$ cholesterol for 8 weeks in a temperature $20-24{ }^{\circ} \mathrm{C}$ and humidity (45-55\%)-controlled environment. The control mice $(\mathrm{n}=5)$ were fed with standard laboratory food. Blood samples were collected from the mice for measurement of plasma glucose, lipids. The pancreas were embedded in OCT compound and frozen immediately in liquid nitrogen for further analysis. All animal procedures were performed in accordance with the National Institutes of Health Animal Care and Use Guidelines. All animal protocols were approved by the Animal Ethics Committee at the Beijing Institute of Geriatrics.

\section{Lipoprotein preparation}

Blood was collected from healthy donors. Plasma LDL fractions were isolated by sequential ultracentrifugation, dialyzed against PBS, and then filter sterilized using a 0.22- $\mu \mathrm{m}$ microfilter. Cholesterol concentrations of the isolated lipoproteins were measured by TC quantification kit.

Measurement of plasma glucose and lipids

The levels of total cholesterol (TC), triglycerides (TG), low-density lipoprotein-cholesterol (LDL-C) and high density lipoprotein-cholesterol (HDL-C) were detected using a kit from Sigma Diagnostics. 


\begin{tabular}{|c|c|c|}
\hline $\mathrm{Col}$ & Cell Physiol Biochem 2012;30:439-449 & \\
\hline and Biochemistry & $\begin{array}{l}\text { DOI: 10.1159/000339037 } \\
\text { Published online: July 06, } 2012\end{array}$ & $\begin{array}{l}\text { @ } 2012 \text { S. Karger AG, Basel } \\
\text { www.karger.com/cpb }\end{array}$ \\
\hline
\end{tabular}

Cell culture

NIT-1 cells derived from mouse pancreatic $\beta$-cells (American Type culture Collection) were cultured in low-glucose Dulbecco's modified Eagle's medium (5mmol/L glucose, Gibico) supplemented with $10 \%$ fetal bovine serum (Hyclone), $100 \mathrm{U} / \mathrm{ml}$ penicilin ( Gibco ) and $0.1 \mathrm{mg} / \mathrm{ml}$ streptomycin (Gibco) at $37^{\circ} \mathrm{C}$ in a humidified atmosphere of $95 \% \mathrm{O}_{2}, 5 \% \mathrm{CO}_{2}$.

\section{Determination of ROS}

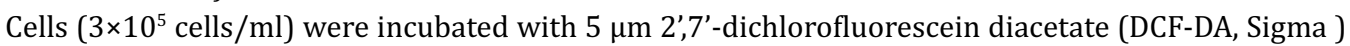
for $30 \mathrm{~min}$ at $37^{\circ} \mathrm{C}$. The $2^{\prime}, 7^{\prime}$-dichlorofluorescein fluorescence was measured by FACS. The sections of OCTembedded pancreas were incubated with $10 \mu \mathrm{m}$ DHE (Sigma) for $15 \mathrm{~min}$ at room temperature. The sections were analyzed by fluorescence microscopy.

\section{Immunofluorescence}

Sections of optimum cutting temperature-embedded pancreas of mice were incubated with polyclonal antibody against NF- $\kappa B$ p50 $(1: 300)$ at $37^{\circ} \mathrm{C}$ for $60 \mathrm{~min}$, and then labeled with TRITC-conjugated anti-rabbit $\operatorname{IgG}(1: 500)$ at $37^{\circ} \mathrm{C}$ for $60 \mathrm{~min}$. Finally, the coverslips were mounted with DABCO (Sigma).

\section{Determination of apoptosis}

To assess the occurrence of apoptosis in NIT-1 cells, the cells were double-stained with Annexin V and a PI kit (Baosai) according to the manufacturer's protocol. Stained nuclei were immediately counted by FACS.

TUNEL in sections of optimum cutting temperature-embedded pancreas of mice was tested by DeadEnd $^{\mathrm{TM}}$ Colorimetric TUNEL System (Promega) according to the manufacturer's protocol. The sections were analyzed by fluorescence microscopy.

\section{siRNA transfection}

The siRNA targeting the mouse NOX2 mRNA was transfected into NIT-1 cells using Tran Messenger ${ }^{\mathrm{TM}}$ Transfection Reagent (Qiagen) according to the manufacturer's instruction. A luciferase siRNA (fluorescein amidite, FAM) was used as a negative control. RNAi oligonucleotides are as follows: for NOX2, 5'UGCCAGAGUCGGGAUUUCUTT-3' (sense) and 5'-AGAAAUCCCGACUCUG -GCATT-3' (anti-sense); for negative control FAM, 5'-UUCUCCGAACGUGUCACG -UTT-3' (sense) and 5'-ACGUGACACGUUCGGAGAATT-3' (antisense).

\section{RNA isolation and real-time PCR}

Total RNA was isolated from NIT-1 cells using Trizol reagent (Invitrogen). Reverse transcription was performed using $1 \mu \mathrm{g}$ RNA at $60^{\circ} \mathrm{C}$ for 35 min using a reverse transcription kit (Promega) containing 0.5 $\mu \mathrm{g}$ random primers, 15 units of avian myeloblastosis virus and 0.5 units of RNasin RNase inhibitor. After reverse transcription, the cDNAs were used for real-time PCR.

Real-time PCR was performed using an A7500 real-time thermal cycler (ABI). The specific primers are as follows: for insulin, 5'-TCTTCTACACACCCATGTCCC -3' (sense) and 5'-GGTGCAGCACTGATCCAC-3' (anti-sense); for GADPH, 5'-CGTCCCGTAGACAAAATGCT-3' (sense) and 5'-TTGATGGCAAC AATCTCC -AC-3' (anti-sense). Amplification was performed as recommended by the manufacturer with a $25 \mu \mathrm{l}$ reaction mixture containing $12.5 \mu \mathrm{l}$ of SYBR Green PCR master mix (Applied Biosystems), the appropriate primer concentration, and $1 \mu \mathrm{l}$ of cDNA. Relative cDNA concentration was established from a standard curve prepared using sequential dilutions of corresponding PCR fragments. The data were normalized to results obtained for glyceraldehydes-3-phosphate dehydrogenase. The amplification program included an initial denaturation at $95^{\circ} \mathrm{C}$ for $10 \mathrm{~min}$, then 30 cycles of denaturation at $95^{\circ} \mathrm{C}$ for $10 \mathrm{~s}$ and annealing and extension at $60^{\circ} \mathrm{C}$ for $1 \mathrm{~min}$. Fluorescence was measured at the end of each extension step. After amplification, melting curves were produced and used to determine the specificity of PCR products.

\section{Protein preparation of whole-cell, nuclei, cytoplasmic fractions}

NIT-1 cells were lysed in lysis buffer containing $50 \mathrm{mmol} / \mathrm{L}$ Tris / $\mathrm{HCl} \mathrm{pH} \mathrm{8.0,150} \mathrm{mmol/L} \mathrm{NaCl,} \mathrm{0.02 \%}$ $\mathrm{NaN}_{3}, 0.1 \% \mathrm{SDS}, 1 \% \mathrm{NP}-40$ (Fluka), $100 \mathrm{mg} / \mathrm{ml}$ phenylmethanesulfonyl fluoride, $1 \mu \mathrm{g} / \mathrm{ml}$ aprotintin and 


\section{Cellular Physiology and Biochemistry

\begin{tabular}{|c|c|}
\hline \multicolumn{2}{|c|}{ Cell Physiol Biochem 2012;30:439-449 } \\
\hline $\begin{array}{l}\text { DOI: } 10.1159 / 000339037 \\
\text { Published online: July 06, } 2012\end{array}$ & $\begin{array}{l}\text { (C) } 2012 \text { S. Karger AG, Basel } \\
\text { www.karger.com/cpb }\end{array}$ \\
\hline
\end{tabular}

0.5\% sodium deoxycholate supplemented with phosphatase inhibitor cocktails (Sigma), and sonicated for $2 \mathrm{~s}$ to shear DNA. Cell lysates were centrifuged at $12000 \mathrm{~g}$ for $10 \mathrm{~min}$. Supernatant was used for Western blot analysis.

Proteins of the nucleic and cytoplasmic fractions of NIT-1 cells were prepared followed by the protocol [1]. The cells were collected and centrifuged for $20 \mathrm{~s}$ in a microcentrifuge, followed by resuspension in buffer 1 containing $10.0 \mathrm{mmol} / \mathrm{L}$ Hepes pH 7.9, $10.0 \mathrm{mmol} / \mathrm{L} \mathrm{KCl}, 1.5 \mathrm{mmol} / \mathrm{L} \mathrm{MgCl}_{2}$ and $0.5 \mathrm{mmol} / \mathrm{L}$ dithiothreitol. After incubation at $4^{\circ} \mathrm{C}$ for $15 \mathrm{~min}$, the cells were lysed using a Dounce homogenizer. The suspension was centrifuged for $20 \mathrm{~s}$ in a microcentrifuge, and the supernatant (cytoplasmic fraction) was collected and frozen. The pellet, which contained the nuclei, was re-suspended in $150 \mu \mathrm{l}$ buffer 2 containing $20 \mathrm{mmol} / \mathrm{L}$ $\mathrm{KCl}, 0.2 \mathrm{mmol} / \mathrm{L}$ EDTA pH 8.0, $0.5 \mathrm{mmol} / \mathrm{L}$ dithiothreitol and $0.5 \mathrm{mmol} / \mathrm{L}$ phenylmethanesulfonyl fluorides. After stirring at $4^{\circ} \mathrm{C}$ for $30 \mathrm{~min}$, the nuclear extracts were centrifuged for $20 \mathrm{~min}$ at $4^{\circ} \mathrm{C}$ in a microcentrifuge. The supernatant was collected and stored at $-80^{\circ} \mathrm{C}$.

Western blot analysis

Cell lysates (15-30 $\mu \mathrm{g}$ of protein) were separated by 10\% SDS-PAGE, transferred to PVDF membrane (Millipore), blocked with $8 \%$ nonfat dry milk, and probed with antibodies at $4{ }^{\circ} \mathrm{C}$ overnight. The blots were incubated with HRP-conjugated anti-IgG, followed by detection with ECL (Millipore). Antibodies against phospho-JNK (Thr ${ }^{183} / \mathrm{Tyr}^{185}$ ), JNK, Akt, phospho-Akt $\left(\mathrm{Ser}^{473}\right)$ and phospho-p53 were purchased from Cell Signaling. Antibodies to FOX01, Bcl2, gp91, p53, PDX-1, NF- $\mathrm{B}, \beta$-actin and PCNA were obtained from Santa Cruz.

Measurement of insulin secretion and cellular insulin content

NIT-1 cells were washed using a modified Krebs/Ringer/bicarbonate/Hepes buffer (KRBH buffer: $140 \mathrm{mmol} / \mathrm{L} \mathrm{NaCl}, 3.6 \mathrm{mmol} / \mathrm{L} \mathrm{KCl}, 0.5 \mathrm{mmol} / \mathrm{L} \mathrm{NaH}_{2} \mathrm{PO}_{4}, 0.5 \mathrm{mmol} / \mathrm{L} \mathrm{MgSO}_{4}, 1.5 \mathrm{mmol} / \mathrm{L} \mathrm{CaCl}_{2}, 2 \mathrm{mmol} /$ $\mathrm{L} \mathrm{NaHCO}_{3}, 10 \mathrm{mmol} / \mathrm{L}$ Hepes, 0.1\% BSA, pH 7.4), and pre-equilibrated using Dulbecco's modified Eagle's medium containing $2.5 \mathrm{mmol} / \mathrm{L}$ glucose for $5 \mathrm{~h}$ at $37^{\circ} \mathrm{C}$. The cells were then incubated for $35 \mathrm{~min}$ in $\mathrm{KRBH}$ buffer containing $2.5 \mathrm{mmol} / \mathrm{L}$ glucose (basal secretion) or KRBH buffer containing $20 \mathrm{mmol} / \mathrm{L}$ glucose (glucose-stimulated insulin secretion). Supernatant was collected and frozen for the insulin assay. The content of insulin was assessed using an ELISA kit (Linco) according to the manufacturer's protocol.

Extraction of cellular cholesterol

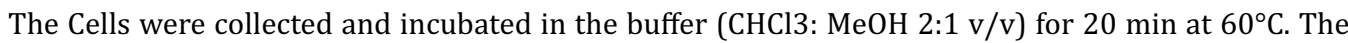
cell lysate was centrifuged at $2000 \mathrm{rpm}$ for $15 \mathrm{~min}$. Supernatant was collected and vacuum freeze-dried. The pellet was dissolved in $\mathrm{H}_{2} \mathrm{O}$. The cholesterol concentration was measured by TC quantification Kit.

Statistical Analysis

All values are represented as means \pm SEM of the indicated number of measurements. A one-way ANOVA test was used to determine significance, with values of $\mathrm{P}<0.05$ indicating statistical significance.

\section{Results}

The apoE ${ }^{-/}$mice display increased plasma cholesterol level, elevated ROS production and decreased insulin content in the pancreatic islets.

The functions of pancreatic $\beta$-cells, such as insulin biosynthesis and secretion, were impaired under the chronic hypercholestrol conditions in diabetes. 10-week-old male apoE1- mice were fed with a high-fat, cholesterol-rich diet containing $21 \%$ fat, $19.5 \%$ casein, and $1.25 \%$ cholesterol for 8 weeks. Total cholesterol, triglyceride and LDL-C levels were significantly increased (Fig. 1A), accompanied by decreased insulin content (Fig. 1B) and increased $\beta$-cell apoptosis in the pancreas of apo $\mathrm{E}^{-/}$mice (Fig. 1C), suggesting deterioration of $\beta$-cell functions. Importantly, levels of ROS in the pancreas of apo $\mathrm{E}^{-/}$mice were significantly elevated, indicating the state of oxidative stress. It is noteworthy that apoE-/- mice fed with control diet displayed higher ROS levels and lower insulin content in the pancreas compared with control mice (Fig. 1D). Moreover, to examine the role of excess generation of ROS in islets, apoE ${ }^{-/-}$mice fed with a high-fat, cholesterol-rich diet were administered with antioxidant 


\section{Cellular Physiology \\ Cell Physiol Biochem 2012;30:439-449 \\ and Biochemistry

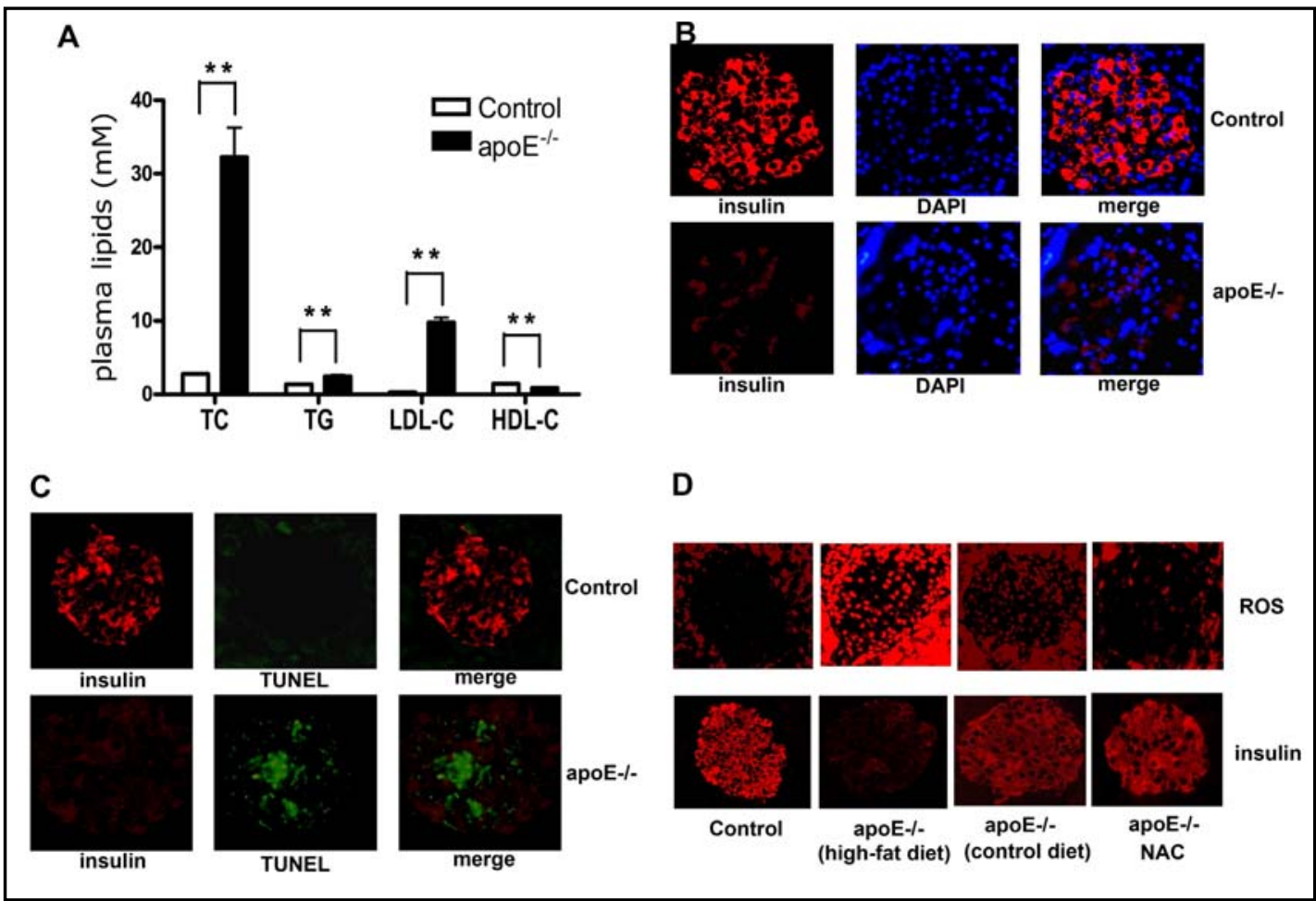

Fig. 1. Analysis of plasma cholesterol, triglyceride, LDL-C, HDL-C, insulin content, and apoptosis and ROS generation in the pancreas of apo: $\mathrm{E}^{-/-}$mice. The apoE $\mathrm{E}^{-/-}$mice were fed with high-fat diet containing $21 \%$ fat, $19.5 \%$ casein, and $1.25 \%$ cholesterol, or with control diet. The levels of plasma cholesterol, triglyceride, LDL-C and HDL-C (A), insulin content (B), apoptosis (C) and ROS production (D) in the pancreas of apoE $\%$ mice. Data represent the means \pm S.E.M., $n=5 .{ }^{* *} \mathrm{p}<0.01$ versus control.

$\mathrm{N}$-acetylcysteine (NAC) (200mg/kg/day) for 8 weeks. As shown in Fig. 1D, ROS generation in the pancreas of apo: $\mathrm{E}^{-/}$mice was impaired while insulin content in the pancreas was increased by NAC administration. These in vivo observations suggested that oxidative stress likely contributes to dysfunction of pancreatic $\beta$-cells under hypercholesterol conditions.

Suppression of NOX2 can reduce ROS generation induced by LDL

Our observations indicate that ROS generation was significantly elevated in the pancreas of apo: $\mathrm{E}^{-/}$mice. However, animal models of apoE $\mathrm{E}^{-/}$mice are complex and accompanied by other factors such as elevated levels of triglyceride. In order to determine the contribution of LDL to oxidative stress, we investigated the effects of LDL on ROS production in pancreatic NIT-1 cells. ROS levels were increased in a dose-dependent manner by exposure of NIT-1 cells to LDL (Fig. 2A). Moreover, ROS levels reached the highest point when NIT-1 cells exposed to LDL for $6 \mathrm{~h}$ (Fig. 2B). We recently found that NOX is a leading candidate for production of ROS in NIT-1 cells. Here, we investigated the effects of NADPH oxidase inhibitor DPI (2.5ìmol/L) on LDL-induced increased ROS levels. As show in Fig. 2C, DPI significantly inhibited generation of ROS in response to LDL treatment. Our analysis of expression profile of NOX family showed that NOX2 and its subunits, such as p22phox, p47phox, p67phox and Rac1, but not of NOX1, NOX3, NOX4 or NOX5, expressed in NIT-1 cells [7]. Therefore, to further determine whether NOX2 is involved in LDL-induced increased ROS generation in NIT-1 cells, siRNA targeting NOX2 mRNA was transfected into NIT-1 cells. As shown in Fig. 2D, transfection of si-NOX2, but not control siRNA (FAM), significantly reduced ROS generation in NIT-1 cells, suggesting that NOX2 may be the possible predominant source of ROS generation induced by LDL.

\section{LDL leads to dysfunction and elevated accumulation of cholesterol in NIT-1 cells}

We next investigated the effects of LDL on the functions of $\beta$-cells. In consistent with the found in vivo, insulin mRNA levels were significantly decreased in the NIT-1 cells by exposure 


\begin{tabular}{|c|c|c|}
\hline \multirow{2}{*}{$\begin{array}{c}\text { Cellular Physiology } \\
\text { and Biochemistry }\end{array}$} & \\
\hline & DOI: $10.1159 / 000339037$ & $\begin{array}{l}\text { C } 2012 \text { S. Karger AG, Basel } \\
\text { www.karger.com/cpb }\end{array}$ \\
\hline
\end{tabular}
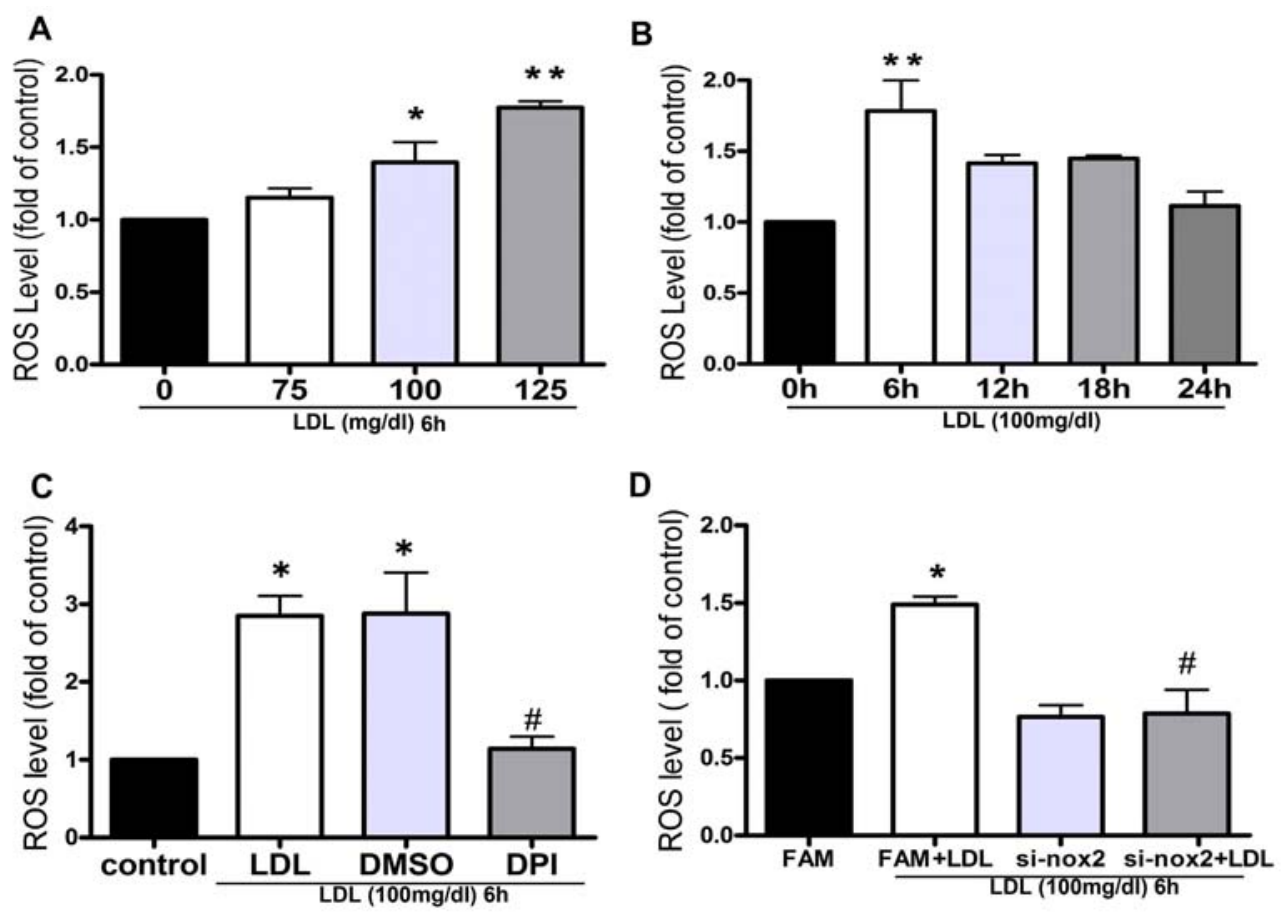

Fig. 2. Suppression of NOX2 can reduce ROS generation induced by LDL. ROS levels were increased in a dose-dependent manner by exposure of NIT-1 cell to LDL (A). The ROS levels reached the highest point when NIT-1 cells exposed to LDL (100mg/dl) for $6 \mathrm{~h}$ (B). NOX inhibitor DPI $(2.5 \mu \mathrm{mol} / \mathrm{L})$ significantly reduced generation of ROS in response to LDL treatment (C). Suppression of NOX2 blocked LDL-induced elevated ROS generation in NIT-1 cells (D). Data represent the means \pm S.E.M., $n=3$ independent experiments. ${ }^{*} \mathrm{p}<0.05,{ }^{* *} \mathrm{p}<0.01$ versus control; \# $\mathrm{p}<0.05$, \#\# $\mathrm{p}<0.01$ versus LDL.
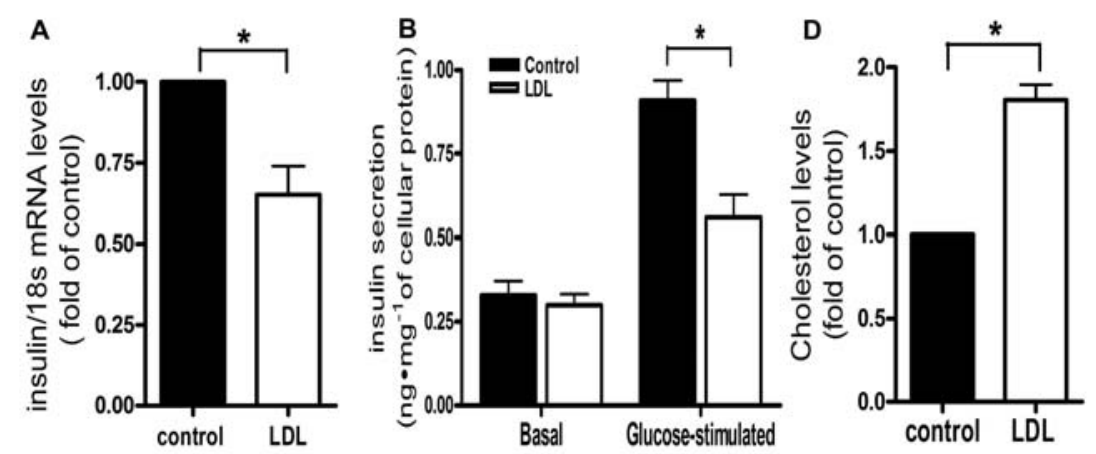

Fig. 3. LDL leads to dysfunction and accumulation of cholesterol in NIT-1 cells. Insulin mRNA levels were significantly decreased in NIT-1 cells by exposure to LDL, as analyzed by real-time PCR (A). ELISA showed unchanged insulin basal insulin secretion $(2.5 \mathrm{mmol} / \mathrm{L}$ D-glucose in $\mathrm{KRBH}$ buffer $)$ and decreased glucose stimulated insulin secretion (20 mmol/L D-glucose in KRBH buffer) in NIT-1 cells in response to LDL (B). The accumulation of intracellular cholesterol was significantly increased in LDL-treated NIT-1 cells (C). Data represent the means \pm S.E.M., $n=3$ independent experiments. * $\mathrm{p}<0.05$ versus control.

to LDL, as analyzed by real-time PCR (Fig. 3A). ELISA showed unchanged insulin basal insulin secretion $(2.5 \mathrm{mmol} / \mathrm{L} \mathrm{D}$-glucose in KRBH buffer) and decreased glucose stimulated insulin secretion (20mmol/L D-glucose in KRBH buffer) in NIT-1 cells in response to LDL 


\begin{tabular}{|c|c|c|}
\hline $108 y$ & Cell Physiol Biochem 2012;30:439-449 & \\
\hline and Biochemistry & $\begin{array}{l}\text { DOI: 10.1159/000339037 } \\
\text { Published online: July 06, } 2012\end{array}$ & $\begin{array}{l}\text { O } 2012 \text { S. Karger AG, Basel } \\
\text { www.karger.com/cpb }\end{array}$ \\
\hline
\end{tabular}

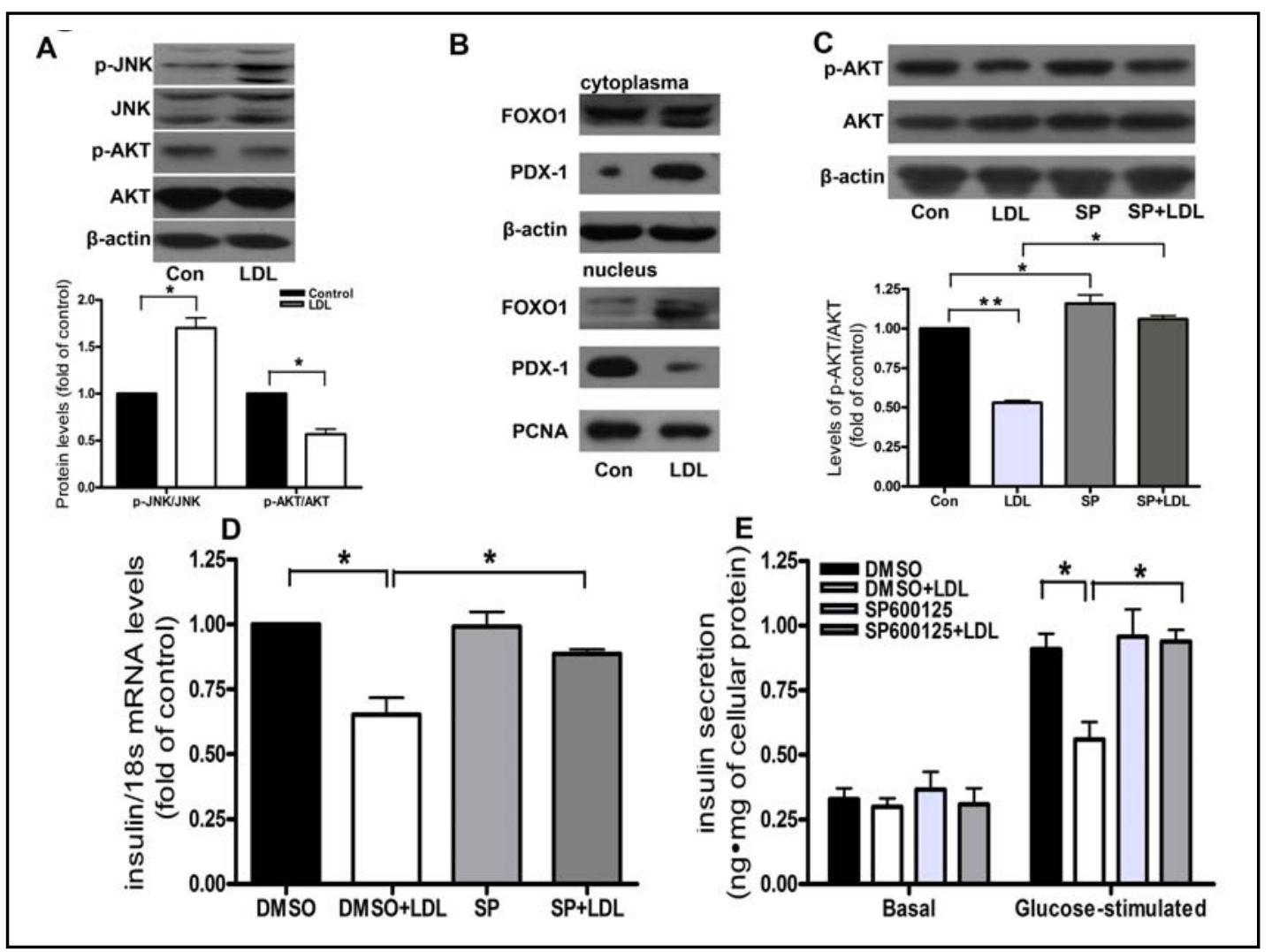

Fig. 4. JNK activation and AKT inhibition are involved in LDL-induced dysfunction of NIT-1 cells. Phosphorylation of JNK (183Thr/185Tyr) was elevated, but phosphorylation of AKT was reduced in NIT-1 cells by exposure to LDL for $24 \mathrm{~h}$ (A). Western blot showed that the FOXO1 content decreased in the cytoplasm but increased in the nucleus. In contrast, the PDX-1 level increased in the cytoplasm but decreased in the nucleus (B). Inhibition of JNK activation by SP6000125 (SP) blocked LDL-induced suppression of insulin mRNA level and glucose-stimulated insulin secretion in NIT-1 cells (C, D, E). Data represent the means \pm S. E.M., $n=3$ independent experiments. ${ }^{*} \mathrm{p}<0.05$ versus control; $\# \mathrm{p}<0.05$ versus LDL.

(Fig. 3B). LDL is the major cholesterol-carrying lipoprotein in plasma. The accumulation of intracellular cholesterol was significantly increased in LDL-treated NIT-1 cells (Fig. 3C).

JNK activation and AKT inhibition are involved in LDL-induced dysfunction of NIT-1 cells

It is reported that activation of JNK is involved in $\beta$-cell dysfunction induced by oxidative stress [9]. To analyze the molecular mechanisms involved in LDL-induced dysfunction of NIT1 cells, JNK transduction pathway was investigated. As shown in Fig. 4A, phosphorylation of JNK (183Thr/185Tyr) was elevated, but phosphorylation of AKT was reduced in NIT-1 cells by exposure to LDL for $24 \mathrm{~h}$. Kawamori D reported that oxidative stress induces the nuclear translocation of forkhead box 01 (FOXO1) and nucleocytoplasmic translocation of pancreatic duodenal homeobox-1 (PDX-1), through activation of JNK pathway [10]. To further analyze the translocation of FOXO1 and PDX-1 in response to LDL, we isolated proteins from nuclei and cytoplasmic fractions of NIT-1 cells after exposure to LDL for $24 \mathrm{~h}$. Western blot showed that the FOXO1 content decreased in the cytoplasm but increased in the nucleus. In contrast, the PDX-1 level increased in the cytoplasm but decreased in the nucleus (Fig. 4B).

In order to further assess the effects of JNK on dysfunction of NIT-1 cells, SP6000125, a JNK inhibitor, was used to inhibit JNK activation. Inhibition of JNK activation blocked LDLinduced suppression of insulin mRNA levels and glucose-stimulated insulin secretion in NIT1 cells (Fig. 4C, D, E). These observations suggest that JNK could play very important role in LDL-induced dysfunction of NIT-1 cells. 


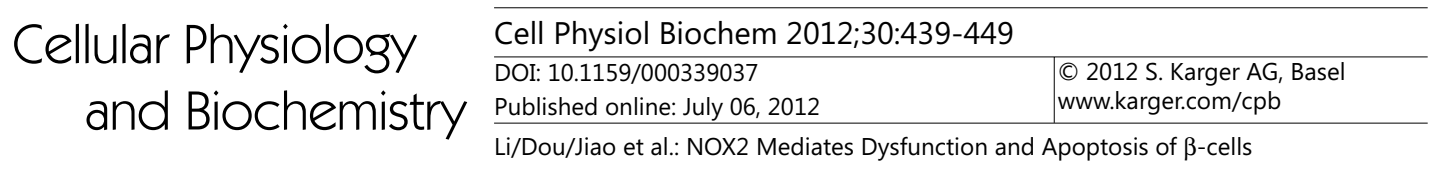

A

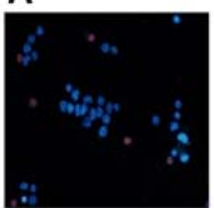

Con

B

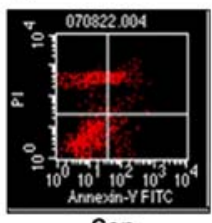

Con

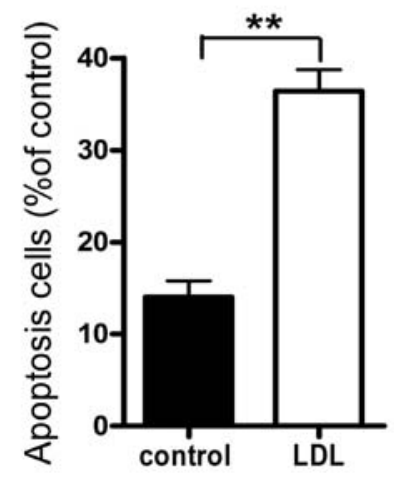

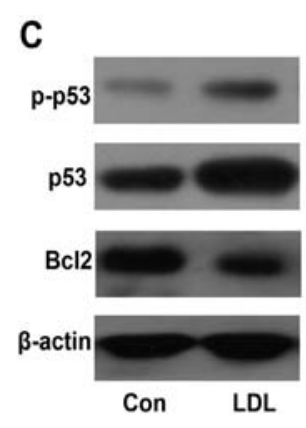
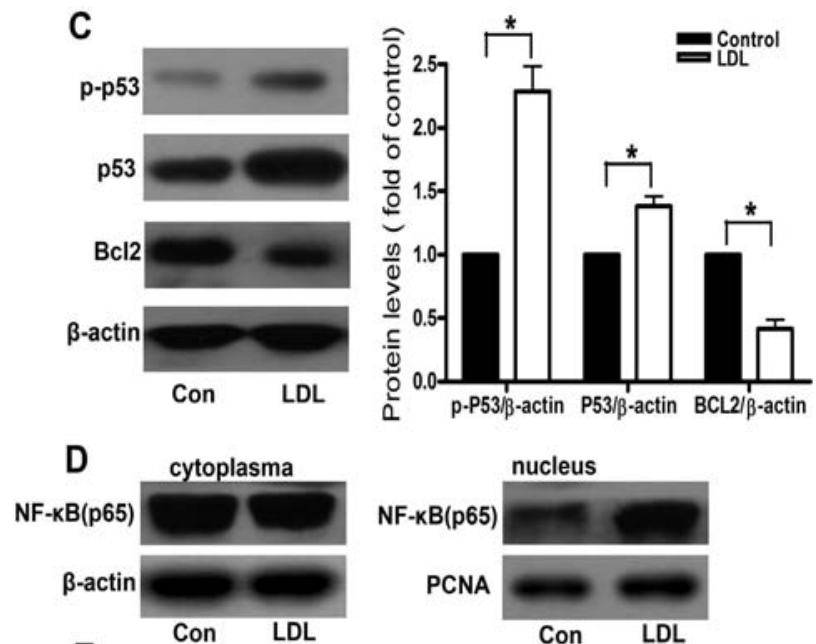

E

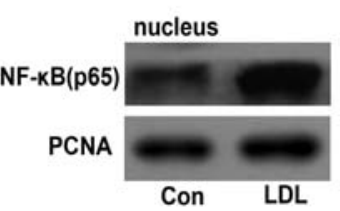

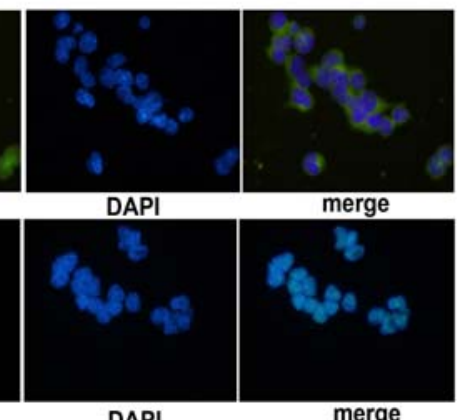

NF-kB(p50)

DAPI

merge

Fig. 5. p53, NF- $\kappa B$ and Bcl2 mediate LDL-induced apoptosis of NIT-1 cells. LDL induces apoptosis of NIT-1 cells, as shown by PI and Hochest33342 double staining (A), and using Annexin V and PI kit (B). LDL stimulated p53 phosphorylation and decreased Bcl2 levels (C). NF- $\kappa B$ content was increased in the nucleus and decreased in the cytoplasm (D). Immunofluorescence showed that NF- $\kappa B$ was translocated into the nucleus in NIT-1 cells by exposure to LDL (E). Data represent the means \pm S.E.M., $n=3$ independent

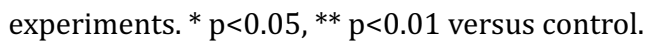

p53, NF- $\kappa B$ and Bcl2 mediate the apoptosis of NIT-1 cells induced by LDL

We next investigated whether LDL induces apoptosis of NIT-1 cells. PI and Hochest33342 double staining showed apoptotic cells in LDL-treated NIT-1 cells (Fig. 5A). Using Annexin $\mathrm{V}$ and PI kit, we also found that rate of apoptosis was significantly elevated in NIT-1 cells treated with LDL (Fig. 5B), suggesting that LDL can induce apoptosis of NIT-1 cells. Moreover, we explored the molecular mechanisms involved in $\beta$-cell apoptosis induced by LDL. It has been reported that phosphorylation level of p53 is response to oxidative stress. Exposure to LDL for $24 \mathrm{~h}$ stimulated phosphorylation of p53 (Fig. 5C). Moreover, NF- $\kappa B$ was involved in apoptosis mediated by $\mathrm{p} 53$. As shown in Fig. 5D, the NF- $\kappa$ B content decreased in the cytoplasm but increased in the nucleus. Consistent with Fig. 5D, immunofluorescence showed that in the unstimulated cells, NF- $\kappa$ B existed in the cytoplasm, while upon stimulation of LDL NF$\kappa \mathrm{B}$ was translocated into the nucleus (Fig. $5 \mathrm{E}$ ). In addition, decreased levels of Bcl2, a key factor leading to apoptosis, were found in NIT-1 cells exposure to LDL (Fig. 5C). These results suggest that $\mathrm{p} 53, \mathrm{NF}-\mathrm{\kappa B}$ and Bcl2 participated in NIT-1 cell apoptosis induced by LDL. 


\begin{tabular}{|c|c|c|}
\hline $108 y$ & Cell Physiol Biochem 2012;30:439-449 & \\
\hline and Biochemistry & $\begin{array}{l}\text { DOI: 10.1159/000339037 } \\
\text { Published online: July 06, } 2012\end{array}$ & $\begin{array}{l}\text { O } 2012 \text { S. Karger AG, Basel } \\
\text { www.karger.com/cpb }\end{array}$ \\
\hline
\end{tabular}

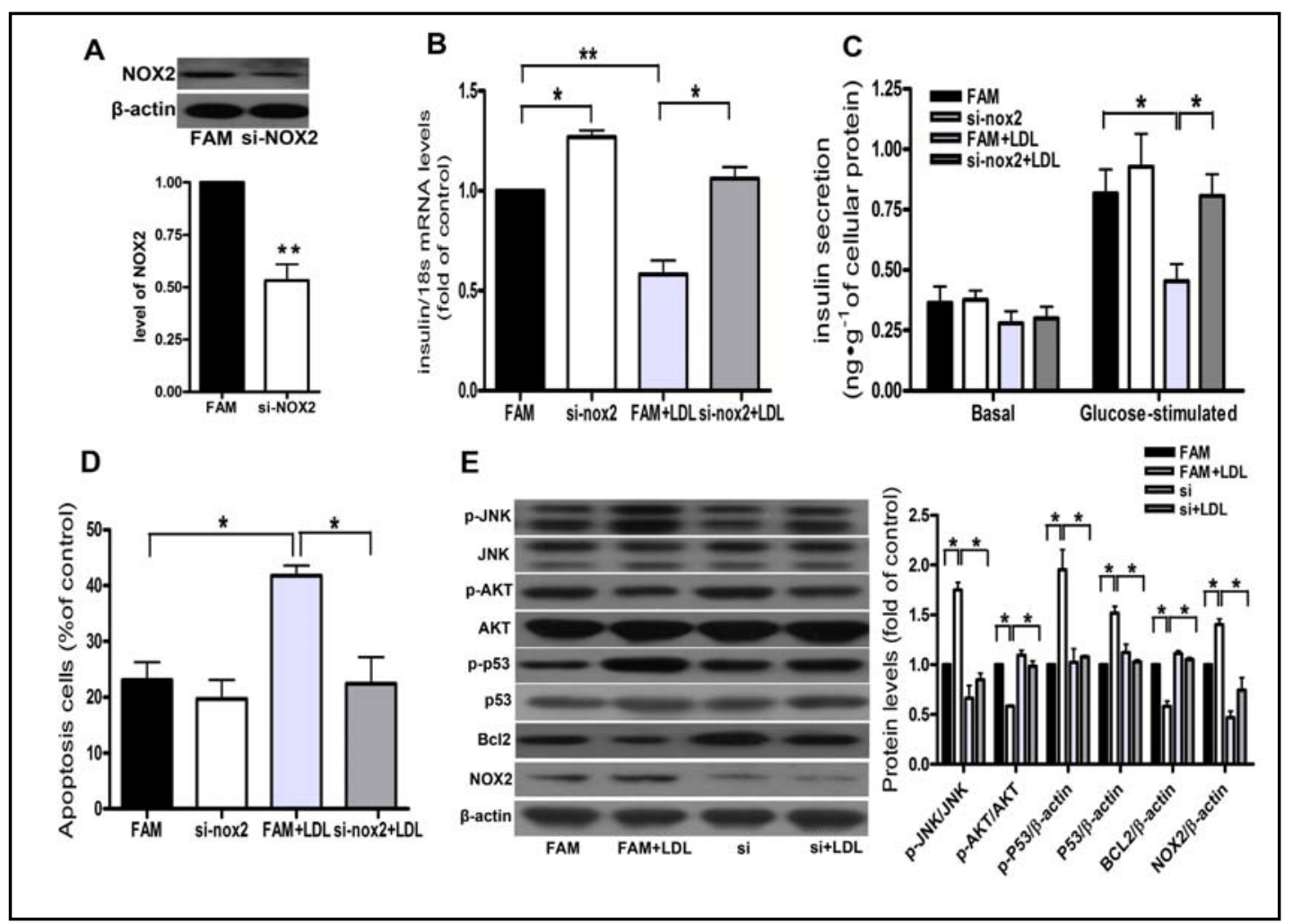

Fig. 6. Suppression of NOX2 substantially blocks LDL-induced dysfunction and apoptosis of NIT-1 cells. NOX2 expression was significantly suppressed in NIT-1 cells transfected with si-NOX2 (A). NOX2 downregulation reversed LDL-induced impaired synthesis and secretion of insulin (B, C). The apoptosis of NIT-1 cells induced by LDL treatment was also blocked by reduction of NOX2 (D). The effects of LDL on activation of JNK and p53 pathways were rescued by transfection of siRNA-NOX2 into NIT-1 cells (E). Data represent the means \pm S.E.M., $n=3$ independent experiments. ${ }^{*} \mathrm{p}<0.05$ versus control; $\# \mathrm{p}<0.05$ versus $\mathrm{LDL}$.

\section{Suppression of NOX2 substantially blocks LDL-induced dysfunction and apoptosis of NIT-1} cells

Finally, to investigate the key role of NOX2 in the dysfunction and apoptosis induced by LDL, siRNA-NOX2 was transfected into NIT-1 cells. The results show that NOX2 expression was significantly suppressed in NIT-1 cells transfected with si-NOX2 (Fig. 6A). NOX2 downregulation reversed LDL-induced impaired synthesis and secretion of insulin (Fig. 6B,C). The apoptosis of NIT-1 cells induced by LDL treatment was also blocked by reduction of NOX2 (Fig. 6D). Moreover, the effects of LDL on activation of JNK and p53 pathways were rescued by transfection of siRNA-NOX2 into NIT-1 cells (Fig. 6E). Taken together, these results suggest that suppression of NOX2 substantially blocks LDL-induced dysfunction and apoptosis of NIT-1 cells.

\section{Discussion}

Various factors contribute to pathogenesis of type 2 diabetes. Elevated levels of plasma cholesterol are a common feature of the patients with type 2 diabetes. In apo: $\mathrm{E}^{-/}$mice, plasma TC and LDL-C levels were dramatically elevated. In agreement with previous study [3], we found that elevated levels of LDL-C and TC in plasma were accompanied by increased apoptosis and decreased insulin content in the pancreatic islet of apoE $\mathrm{E}^{-/-}$mice. Because apo: $\mathrm{E}^{-/}$mice are complex and accompanied by other factors such as elevated triglyceride levels, it is difficult to determine the contribution of LDL to oxidative stress and pancreatic $\beta$-cell dysfunction. Therefore, we extended these observations from apo $\mathrm{E}^{-/}$mice to a mouse pancreatic $\beta$-cell 


\section{Cellular Physiology Cell Physiol Biochem 2012;30:439-449 \\ \begin{tabular}{ll|l} 
and Biochemistry & $\begin{array}{l}\text { DOI: 10.1159/000339037 } \\
\text { Published online: July 06, } 2012\end{array}$ & $\begin{array}{l}\text { C 2012 S. Karger AG, Basel } \\
\text { www.karger.com/cpb }\end{array}$ \\
\cline { 2 - 3 } Li/Dou/Jiao et al.: NOX2 Mediates Dysfunction and Apoptosis of $\beta$-cells
\end{tabular}}

line NIT-1. In fact, pancreatic $\beta$-cells were found to express various lipoprotein receptors including members of the LDL receptor gene family. LDL receptors mediated the endocytosis of lipoprotein [11]. A large body of evidence showed that LDL can induce pancreatic $\beta$-cell necrosis $[3,4]$, dysfunction $[3,12]$ and apoptosis. It has been reported that LDL-induced dysfunction and apoptosis of $\beta$-cells can be prevented by inhibiting the binding of LDL to its receptor [12]. LDL toxicity is attributable to an oxidative process, because it is prevented by inhibiting the activation of oxidation catalyzers [4]. Intracellular oxidation of LDL lipid in $\beta$-cells is expected to form reactive peroxides of cholesterol to propagate complex oxidative stress reaction. Therefore, LDL can be up-taken and oxidative modificated in $\beta$-cells. In consistent, our study shows that accumulation of intracellular cholesterol was significantly increased in NIT- 1 cells by exposure to LDL for $24 \mathrm{~h}$. However, it is reported that $1.6 \mathrm{mmol} / \mathrm{L}$ to $3.1 \mathrm{mmol} / \mathrm{L}$ native LDL could not induce oxidative stress of $\beta$-cells [13]. In contrast to previous report, we observed elevated ROS generation in the pancreas of apoE $\mathrm{E}^{-/}$mice fed with both high-fat, cholesterol-rich diet and control diet, and in NIT-1 cells exposure to LDL $(100 \mathrm{mg} / \mathrm{dl})$ for $6 \mathrm{~h}$. We consider that different results are due to different dose of LDL and different $\beta$-cell lines used in experiments.

It is has been proved that ROS are produced through various pathways, such as NOX, the mitochondrial electron transport chain, nitric oxide synthase and xanthine oxidase. It is proposed that NOX enzyme is a potential source of ROS production in pancreatic $\beta$-cells and involved in the pathogenesis of type 2 diabetes $[14,15]$. Recently, by observing the effects of different inhibitors of ROS-generating systems, we demonstrated that NOX may be the predominant source of ROS in NIT-1 cells, although rotenone, a mitochondrial respiratory chain inhibitor, may partially inhibit generation of ROS in response to glucose and free fatty acids. Moreover, analysis of expression profile of NOX family in NIT-1 cells showed expression of NOX2 and its subunits, such as p22phox, p47phox, p67phox and Rac1, but not of NOX1, NOX3, NOX4 or NOX5 in NIT-1 cells (data not shown). In the present study, we found that LDL-induced ROS production in NIT-1 cells was significantly reduced by DPI. Moreover, LDLinduced elevated ROS generation and impaired insulin synthesis and decreased glucosestimulated insulin secretion were reversed by transfection of siRNA-NOX2 into NIT-1 cells, suggesting that NOX2 may be the possible predominant source of ROS generation induced by LDL.

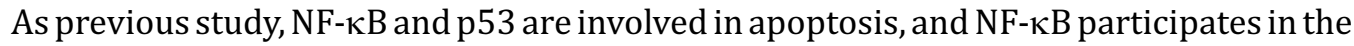
process of apoptosis mediated by p53 [16]. Our study suggests that $\mathrm{p} 53$ phosphorylation and NF- $\kappa B$ levels in nuclei were elevated in NIT-1 cells by exposure to LDL. It has been determined that low does oxidized LDL can induce dysfunction of $\beta$-cells by activation of JNK pathway. Our data show that phosphorylation of JNK was increased, and phosphorylation of AKT was reduced in NIT- 1 cells by exposure to LDL $(100 \mathrm{mg} / \mathrm{dl})$. NIT- 1 cell dysfunction induced by LDL was reversed by inhibition of JNK activation, as assessed by treatment with SP6000125, a JNK inhibitor. Moreover, LDL-induced JNK activation and AKT inhibition resulted in nuclear translocation of FOXO1 and nucleocytoplasmic translocation of PDX-1 in NIT-1 cells. It has been proved that FOXO1 can inhibit PDX-1 transcription, suggesting that it is involved in the dysfunction of $\beta$-cells [10]. Oxidative stress contributed to nuclear translocation of FOXO1 via activation of JNK pathway, leading to nucleocytoplasmic translocation of PDX-1 [17]. It is proposed that transcription factor PDX-1 improves the growth, proliferation and functions of $\beta$-cells. LDL induced reduction of insulin mRNA levels in NIT-1 cells is associated with a decrease in PDX-1 expression in nuclei, suggesting the important role of PDX-1 in $\beta$-cell dysfunction. More importantly, LDL-induced activation of JNK and inhibition of AKT were reversed by NOX2 down-regulation in NIT-1 cells, indicating a critical role of NOX2-derived ROS in the deterioration of $\beta$-cell function.

In conclusion, we provide novel data indicating that the effects of LDL on dysfunction and apoptosis of pancreatic $\beta$-cells appear to be, at least in part, mediated by NOX2-derived ROS through JNK and p53 pathways. 


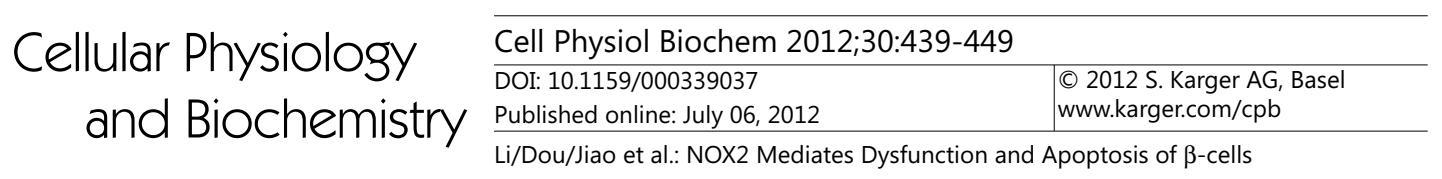

Acknowledgements

We would like to thank Prof. Yi Zhu (Peking University Health Science Center) for providing NIT-1 cells. This work was supported by grants from National Basic Research Program of China (2012CB517502) and National Natural Science Foundation of China (81070634).

\section{References}

1 Kahn SE, Hull RL, Utzschneider KM: Mechanisms linking obesity to insulin resistance and type 2 diabetes. Nature 2006;444:840-846.

2 Shepherd J: Dyslipidaemia in diabetic patients: time for a rethink. Diabetes Obes Metab 2007;9:609-616.

3 Hao M, Head WS, Gunawardana SC, Hasty AH, Piston DW: Direct effect of cholesterol on insulin secretion: a novel mechanism for pancreatic beta-cell dysfunction. Diabetes 2007;5:2328-2338.

4 Cnop M, Hannaert JC, Grupping AY, Pipeleers DG: Low density lipoprotein can cause death of islet beta-cells by its cellular uptake and oxidative modification. Endocrinology 2002;143:3449-3453.

5 Newsholme P, Morgan D, Rebelato E, Oliveira-Emilio HC, Procopio J, Curi R, Carpinelli A: Insights into the critical role of NADPH oxidase(s) in the normal and dysregulated pancreatic beta cell. Diabetologia 2009;52:2489-2498.

6 Houstis N, Rosen ED, Lander ES: Reactive oxygen species have a causal role in multiple forms of insulin resistance. Nature 2006;440:944-948.

7 Bedard K, Krause KH: The NOX family of ROS-generating NADPH oxidases: physiology and pathophysiology. Physiol Rev 2007;87:245-313.

8 Morgan D, Rebelato E, Abdulkader F, Graciano MF, Oliceira-Emilio HR, Hirata AE, Rocha MS, Bordin S, Curi R, Carpinelli AR: Association of NAD(P)H oxidase with glucose-induced insulin secretion by pancreatic beta-cells. Endocrinology 2009;150:2197-2201.

9 Kaneto H, Matsuoka TA, Katakami N, Kawamori D, Miyatsuka T, Yoshiuchi K, Yasuda T, Sakamoto K, Yamasaki K, Matsubisa M: Oxidative stress and the JNK pathway are involved in the development of type 1 and type 2 diabetes. Curr Mol Med 2007;7:674-686.

10 Kawamori D, Kaneto H, Nakatani Y, Matsuoka TA, Matsuhisa M, Hori M, Yamasaki Y: The forkhead transcription factor Foxo1 bridges the JNK pathway and the transcription factor PDX-1 through its intracellular translocation. J Biol Chem 2006;281:1091-1098.

11 Fujino T, Asaba H, Kang MJ, Ikeda Y, Sone H, Takada S, Kim DH, Ioka RX, Ono M, Tomoyori H, Okubo M, Murase T, Kamataki A, Yamamoto J, Magoori K, Takahashi S, Miyamoto Y, Oishi H, Nose M, Okazaki M, Usui S, Imaizumi K, Yanagisawa M, Sakai J, Yamamoto TT: Low-density lipoprotein receptor-related protein 5 (LRP5) is essential for normal cholesterol metabolism and glucose-induced insulin secretion. Proc Natl Acad Sci U S A 2003;100:229-234.

12 Roehrich ME, Mooser V, Lenain V, Herz J, Nimpf J, Azhar S, Bideau M, Capponi A, Nicod P, Haefiger JA, Waeber G: Insulin-secreting beta-cell dysfunction induced by human lipoproteins. J Biol Chem 2003;278:18368-18375.

13 Abderrahmani A, Niederhauser G, Favre D, Abdelli S, Ferdaoussi M, Yang JY, Regazzi R, Widmann C, Waeder G: Human high-density lipoprotein particles prevent activation of the JNK pathway induced by human oxidised low-density lipoprotein particles in pancreatic beta cells. Diabetologia 2007;50:1304-1314.

14 Guichard C, Moreau R, Pessayre D, Epperson TK, Krause KH: NOX family NADPH oxidases in liver and in pancreatic islets: a role in the metabolic syndrome and diabetes? Biochem Soc Trans 2008;36:920-929.

15 Kakehi T, Yabe-Nishimura C: NOX enzymes and diabetic complications. Semin Immunopathol 2008;30:301314.

16 Zhou M, Gu L, Zhu N, Woods WG, Findley HW: Transfection of a dominant-negative mutant NF-kB inhibitor $(\mathrm{IkBm})$ represses p53-dependent apoptosis in acute lymphoblastic leukemia cells: interaction of IkBm and p53. Oncogene 2003;22:8137-8144.

17 Kawamori D, Kajimoto Y, Kaneto H, Umayahara Y, Fujitani Y, Miyatsuka T, Watada H, Leibiger IB, Yamasaki Y, Hori M: Oxidative stress induces nucleo-cytoplasmic translocation of pancreatic transcription factor PDX-1 through activation of c-Jun NH(2)-terminal kinase. Diabetes 2003;52:2896-28904. 